\title{
Volume Anestésico Mínimo para Bloqueio Retrobulbar Extraconal: Comparação entre Soluções a 0,5\% de Bupivacaína Racêmica, de Levobupivacaína e da Mistura Enantiomérica S75/R25 de Bupivacaína *
}

\section{Minimum Anesthetic Volumes for Extraconal Retrobulbar Block: Comparison between 0.5\% Racemic Bupivacaine, Levobupivacaine and Enantiomeric Mixture S75/R25 Bupivacaine}

Luiz Fernando Soares, TSA ${ }^{1}$; Ana Claudia de Melo Barros ${ }^{2}$; Gustavo Paiva Almeida ${ }^{2}$; Gustavo Luchi Boos ${ }^{3}$; Getúlio Rodrigues de Oliveira Filho, TSA ${ }^{4}$

\section{RESUMO}

Soares LF, Barros ACM, Almeida GP, Boos GL, Oliveira Filho GR Volume Anestésico Mínimo para Bloqueio Retrobulbar Extraconal: Comparação entre Soluções a 0,5\% de Bupivacaína Racêmica, de Levobupivacaína e da Mistura Enantiomérica S75/R25 de Bupivacaína

JUSTIFICATIVA E OBJETIVOS: O volume anestésico mínimo (VAM) de um anestésico local é o volume efetivo para anestesia regional em $50 \%$ dos pacientes. O objetivo deste estudo foi calcular os volumes anestésicos mínimos das soluções a 0,5\% de bupivacaína racêmica, de levobupivacaína e da mistura enantiomérica S75/R25 de bupivacaína para anestesia retrobulbar extraconal.

MÉTODO: Foram estudadas duas séries de pacientes submetidos à extração de catarata. Na série 1 , os pacientes receberam bupivacaína a $0,5 \%(n=9)$ ou levobupivacaína a $0,5 \%(n=11)$. $\mathrm{Na}$ série 2, os pacientes receberam bupivacaína racêmica a 0,5\% $(n=11)$ ou a mistura enantiomérica S75/R25 de bupivacaína a $0,5 \%(n=10)$. Os bloqueios foram realizados por injeção única ínfero-lateral. A mobilidade de cada músculo reto foi avaliada após 10 minutos como: 0 (ausente), 1 (diminuída) ou 2 (normal). A soma dos escores constituiu o escore total de mobilidade (ETM) do globo ocular. O volume inicial foi de 7,4 $\mathrm{mL}$. Os volumes utilizados em pacientes subseqüentes corresponderam 0,1 unidade logarítmica maior $(E T M>2)$ ou menor $(E T M \leq 2)$ que o logaritmo natural do volume precedente. Foram utilizadas as fórmulas de Massey e Dixon para cálculos dos VAM.

RESULTADOS: Os volumes anestésicos mínimos da bupivacaína racêmica foram $6 \mathrm{~mL}$ e 6,2 $\mathrm{mL}$, o da levobupivacaína foi $5,7 \mathrm{~mL}$ e o

\footnotetext{
* Recebido do (Received from) Hospital Governador Celso Ramos, CET/SBA Integrado de Anestesiologia da Secretaria de Estado da Saúde de Santa Catarina (SES-SC), Florianópolis, SC

1. Instrutor Co-Responsável, Chefe do Núcleo de Educação e Pesquisa em Anestesia para Oftalmologia, CET/SBA Integrado de Anestesiologia da SES-SC

2. $M E_{2}, C E T / S B A$ Integrado de Anestesiologia da SES-SC

3. $\mathrm{ME}_{3}, \mathrm{CET} / \mathrm{SBA}$ Integrado de Anestesiologia da SES-SC

4. Responsável, CET/SBA Integrado de Anestesiologia da SES-SC
}

Apresentado (Submitted) em 17 de janeiro de 2005

Aceito (Accepted) para publicação em 24 de fevereiro de 2005

Endereço para correspondência (Correspondence to)

Dr. Getúlio Rodrigues de Oliveira Filho

Rua Luiz Delfino 111/902

88015-360 Florianópolis, SC

E-mail: grof@th.com.br

(C) Sociedade Brasileira de Anestesiologia, 2005 da mistura enantiomérica de bupivacaína $S 75 / R 25$ foi 5, $8 \mathrm{~mL}$. Não houve diferença entre os grupos quanto aos volumes anestésicos efetivos.

CONCLUSÕES: Volumes semelhantes de soluções a $0,5 \%$ de bupivacaína racêmica, levobupivacaína ou da mistura enantiomérica $S 75 / R 25$ de bupivacaína são necessários para anestesia retrobulbar extraconal.

Unitermos: ANESTÉSICOS, Local: bupivacaína, levobupivacaína, mistura enantiomérica S75/R25 de bupivacaína; TÉCNICAS ANESTÉSICAS, Regional: bloqueio retrobulbar extraconal

\section{SUMMARY}

Soares LF, Barros ACM, Almeida GP, Boos GL, Oliveira Filho GR Minimum Anesthetic Volumes for Extraconal Retrobulbar Block: Comparison between 0.5\% Racemic Bupivacaine, Levobupivacaine and Enantiomeric Mixture S75/R25 Bupivacaine

BACKGROUND AND OBJECTIVES: Minimum anesthetic volume (MAV) of local anesthetics corresponds to the effective volume for regional anesthesia in $50 \%$ of patients. In this study, MAV of $0.5 \%$ racemic bupivacaine, $0.5 \%$ levobupivacaine and enantiomeric S75/R25 bupivacaine were calculated and compared.

METHODS: This study involved two series of patients undergoing cataract extraction. Series 1 patients received either $0.5 \%$ racemic bupivacaine $(n=9)$ or $0.5 \%$ levobupivacaine $(n=11)$. Series 2 patients received either $0.5 \%$ racemic bupivacaine $(n=11)$ or $0.5 \%$ enantiomeric S75/R25 bupivacaine $(n=10)$. Blockades were achieved by single-injection and inferior-lateral approach. Motility of each rectus muscle was assessed 10 minutes later as: 0 (absent), 1 (decreased) or 2 (normal). Total muscle scores represented total eye motility score (TMS). Local anesthetic volume administered to the first patient of each group was $7.4 \mathrm{~mL}$. Subsequent patients received volumes corresponding to 0.1 higher natural logarithm unit (if $T M E>2$ ) or lower (if $T M E \leq 2$ ) as compared to natural logarithm of preceding volume. Massey and Dixon's formulae were used for MAV calculations.

RESULTS: MAVs of bupivacaine in both series were $6 \mathrm{~mL}$ and 6.2 $m L$, respectively. MAVs of levobupivacaine and enantiomeric S75/R25 bupivacaine were $5.7 \mathrm{~mL}$ and $5.8 \mathrm{~mL}$, respectively. There were no differences between groups in effective anesthetic volumes.

CONCLUSIONS: Similar volumes of $0.5 \%$ racemic bupivacaine, $0.5 \%$ levobupivacaine and enantiomeric S75/R25 bupivacaine are needed for extraconal retrobulbar anesthesia.

Key Words: ANESTHETICS, Local: bupivacaine, enantiomeric mixture S75/R25 bupivacaine, levobupivacaine; ANESTHETIC TECHNIQUES, Regional: extraconal retrobulbar block 


\section{INTRODUÇÃO}

$\mathrm{O}$ volume anestésico mínimo de um anestésico local (VAM) corresponde ao volume efetivo para anestesia regional em $50 \%$ das pacientes; foi introduzido como ferramenta de investigação para comparar os volumes de bupivacaína a $0,5 \%$ e de ropivacaína a $0,5 \%$ para bloqueio do nervo femoral ${ }^{1}$. Para determinar o VAM de um dado anestésico local, a sua concentração deve ser mantida constante. O método de alocação seqüencial dependente da resposta do paciente anterior (método up-down de Massey e Dixon) foi utilizado para o cálculo do VAM e tem como principais vantagens a diminuição do número de pacientes expostos a falhas de anestesia, além da redução substancial do tamanho da amostra ${ }^{2,3}$.

Além de permitir comparações entre diferentes anestésicos locais ${ }^{1}$, o cálculo do VAM pode ser utilizado para comparações entre diferentes concentrações de um mesmo anestésico local ou do efeito de drogas adjuvantes sobre o volume de anestésicos locais nos bloqueios nervosos.

No caso específico do bloqueio retrobulbar extraconal, o volume de anestésico local injetado na cavidade orbitária assume papel fundamental, uma vez que está diretamente relacionado com aumento da pressão intra-ocular ${ }^{4}$.

A bupivacaína racêmica tem se mostrado eficaz para o bloqueio peribulbar ${ }^{5}$. Asua principal desvantagem está relacionada à cardiotoxicidade, pela qual o enantiômero dextrógiro é o principal responsável ${ }^{6}$. O enantiômero levógiro (levobupivacaína)é menos cardiotóxico do que a mistura racêmica ${ }^{7}$. Com o intuito de manter a potência e reduzir a toxicidade da bupivacaína, foi desenvolvida uma mistura enantiomérica contendo $75 \%$ do enantiômero levógiro e $25 \%$ do dextrógiro (S75/R25), que se mostrou menos tóxica do que a mistura racêmica ${ }^{8}$.

Os volumes efetivos mínimos tanto da bupivacaína, da levobupivacaína ou da mistura enantiomérica S75/R25 de bupivacaína para produzir acinesia ocular e anestesia cirúrgica em bloqueios retrobulbares extraconais não foram ainda determinados. Este estudo teve como objetivo definir e comparar os volumes anestésicos mínimos das soluções a $0,5 \%$ de bupivacaína racêmica, de levobupivacaína e da mistura enantiomérica S75/R25 de bupivacaína para anestesia retrobulbar extraconal.

\section{MÉTODO}

Com a aprovação do Comitê de Ética institucional e o respectivo consentimento informado dos pacientes, foram estudadas duas séries de pacientes de ambos os sexos, com idades entre 18 e 85 anos, submetidas eletivamente à extração de catarata por técnica extracapsular ou por facoemulsificação. Os pacientes não receberam medicação pré-anestésica e foram monitorizados com cardioscópio, monitor de pressão arterial não-invasiva automático e oxímetro de pulso. Foi puncionada uma veia periférica com cânula $20 \mathrm{G}$ na mão não dominante e iniciada infusão de solução fisiológica a 0,9\% (2 $\mathrm{mL} \cdot \mathrm{min}^{-1}$ ).
Na série 1, destinada a comparar os volumes anestésicos mínimos da bupivacaína racêmica a $0,5 \%$ e da levobupivacaína a $0,5 \%$, foram incluídos 20 pacientes, que receberam bupivacaína a $0,5 \%(n=9)$ ou levobupivacaína a $0,5 \%(n=11)$. Na série 2, destinada a comparar os volumes anestésicos mínimos da bupivacaína racêmica e da mistura enantiomérica S75/R25 de bupivacaína a 0,5\%, foram incluídos 21 pacientes que receberam bupivacaína racêmica a $0,5 \%$ ( $n=$ 11) ou mistura enantiomérica $S 75 / R 25$ de bupivacaína a $0,5 \%(n=10)$. Os pacientes de cada série foram alocados nos respectivos grupos, segundo seqüência de números aleatórios gerados eletronicamente. Todas a soluções continham adrenalina a 1:200.000.

Ainjeção retrobulbar extraconal foi realizada por via transcutânea ínfero-lateral com agulha $25 \mathrm{G}$ de $2,5 \mathrm{~cm}$ de comprimento. Aagulha foi inserida $1 \mathrm{~cm}$ perpendicularmente à pele e, em seguida, avançada 1,5 cm discretamente para cima e para dentro em direção ao ápice da órbita. Após aspiração negativa de sangue, líquor ou humor vítreo, o volume pré-determinado de anestésico local era injetado. Logo após, um baroftalmo de 600 g era posicionado sobre o globo ocular por 10 minutos. Para cálculo dos volumes a serem utilizados em cada seqüência, considerou-se o volume máximo de $10 \mathrm{~mL}$, que foi transformado em logaritmo natural. Deste, foram subtraídos 0,1 unidade até 10 postos abaixo. Estes valores foram transformados em volumes $(\mathrm{mL})$ calculando os respectivos antilogaritmos. $O$ volume administrado ao primeiro paciente de cada grupo foi de $7,4 \mathrm{~mL}$.

Os volumes subseqüentes foram determinados de acordo com a resposta de cada paciente, em cada grupo. A mobilidade de cada músculo reto foi avaliada 10 minutos após a injeção e os seguintes escores foram atribuídos a cada músculo: 0 (ausente), 1 (diminuída) e 2 (normal). A soma dos escores dos músculos retos constituiu o escore total de mobilidade do globo ocular ${ }^{9}$. Se o escore total de mobilidade fosse superior a dois, $3 \mathrm{~mL}$ de lidocaína a $2 \%$ eram injetados por acesso súpero-medial ou ínfero-lateral, o resultado era considerado falha e o próximo paciente recebia o volume imediatamente superior. Caso contrário, o resultado era considerado sucesso e o próximo paciente recebia o volume de anestésico imediatamente inferior. Os volumes anestésicos mínimos foram calculados pelas fórmulas de Massey e Dixon, para amostras nominais de tamanho igual a seis ${ }^{2,3}$. Os logaritmos naturais dos volumes que se associaram com sucesso dos bloqueios foram comparados, entre os grupos, por análise de variância unifatorial $^{2}$. Valores de p menores que $5 \%$ foram considerados significativos.

\section{RESULTADOS}

Na série 1, o VAM padrão da bupivacaína foi $6 \mathrm{~mL}$ e o da levobupivacaína foi 5,7 $\mathrm{mL}$ (Figuras 1 e 2). Na série 2, o VAM da bupivacaína racêmica foi 6,2 e o da mistura enantiomérica de bupivacaína S75/R25 foi 5,8 mL (Figuras 3 e 4). Não houve diferença entre os logaritmos naturais dos volumes associados com sucesso dos bloqueios $(F(2,24)=0,5 ; p=0,61)$. Sete pacientes em cada série necessitaram de injeção comVol. 55, N 3, Maio - Junho, 2005 
plementar e estão representados por círculos nas figuras. Após complementação, todos puderam ser submetidos às cirurgias propostas.

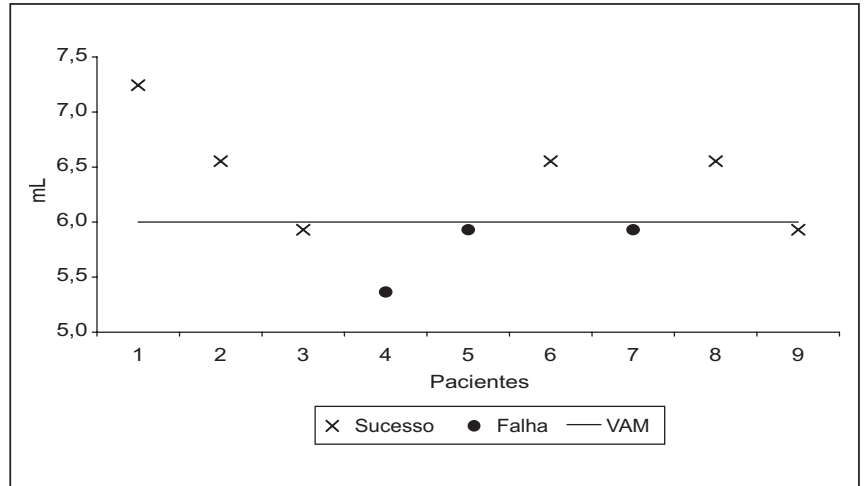

Figura 1 - Seqüência de Respostas dos Pacientes da Série 1 que Receberam Bupivacaína a 0,5\%

$x=$ sucesso (escore total de mobilidade ocular $\leq 2$ ), $\bullet=$ insucesso (escore total de mobilidade ocular $>2$ ). A linha horizontal representa o VAM $(6 \mathrm{~mL})$

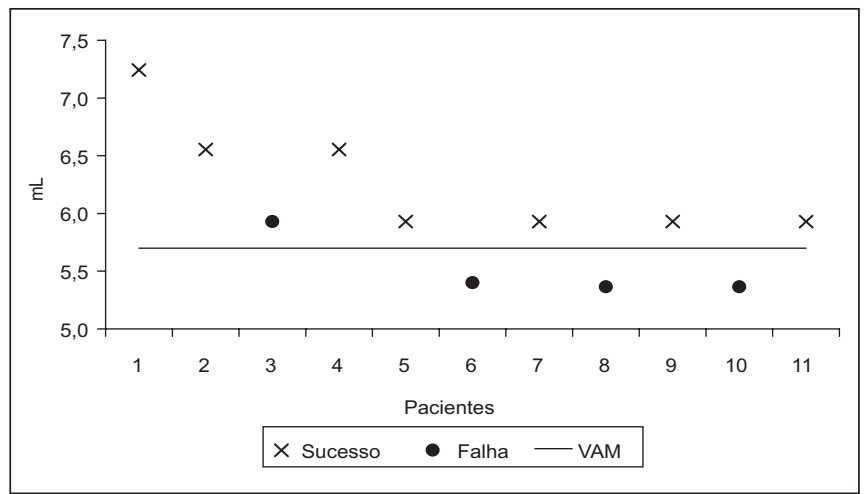

Figura 2 - Seqüência de Respostas dos Pacientes da Série 1 que Receberam Levobupivacaína a 0,5\%

$x=$ sucesso (escore total de mobilidade ocular $\leq 2$ ), $\bullet$ = insucesso (escore total de mobilidade ocular $>2$ ). A linha horizontal representa o VAM $(5,7 \mathrm{~mL})$

\section{DISCUSSÃO}

O principal resultado deste estudo mostrou que não houve diferença entre os volumes anestésicos mínimos da bupivacaína racêmica, da levobupivacaína, ou da mistura enantiomérica S75/R25 de bupivacaína.

Considerando que a potência de uma droga é uma relação entre a massa administrada e efeito ${ }^{10}$, que o mesmo volume de duas soluções de mesma concentração de substâncias de mesmo peso molecular possuem a mesma massa e que o peso molecular dos dois enantiômeros da bupivacaína é $288,4{ }^{11}$, pode-se inferir que, no bloqueio retrobulbar extraconal, as três soluções testadas apresentaram potências semelhantes.

Revista Brasileira de Anestesiologia

Vol. 55, № 3, Maio - Junho, 2005

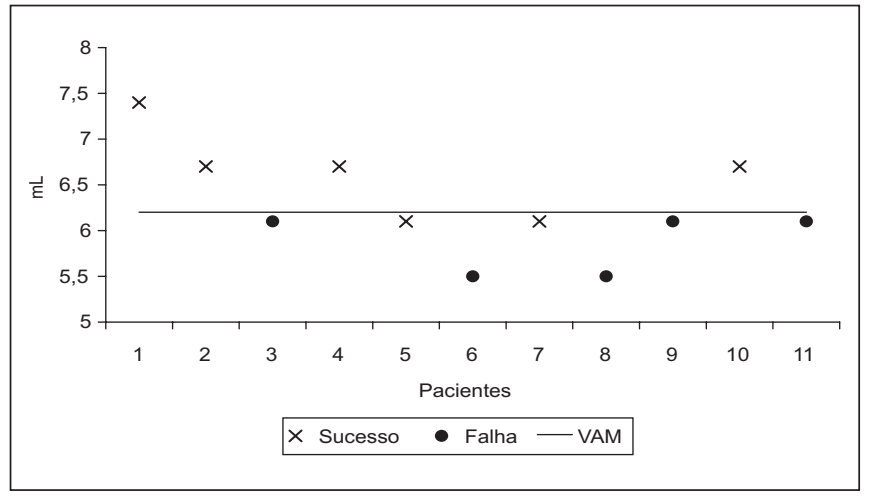

Figura 3 - Seqüência de Respostas dos Pacientes da Série 2 que Receberam Bupivacaína a 0,5\%

$x=$ sucesso (escore total de mobilidade ocular $\leq 2$ ), $\bullet$ = insucesso (escore total de mobilidade ocular $>2$ ). A linha horizontal representa o VAM $(6,2 \mathrm{~mL})$

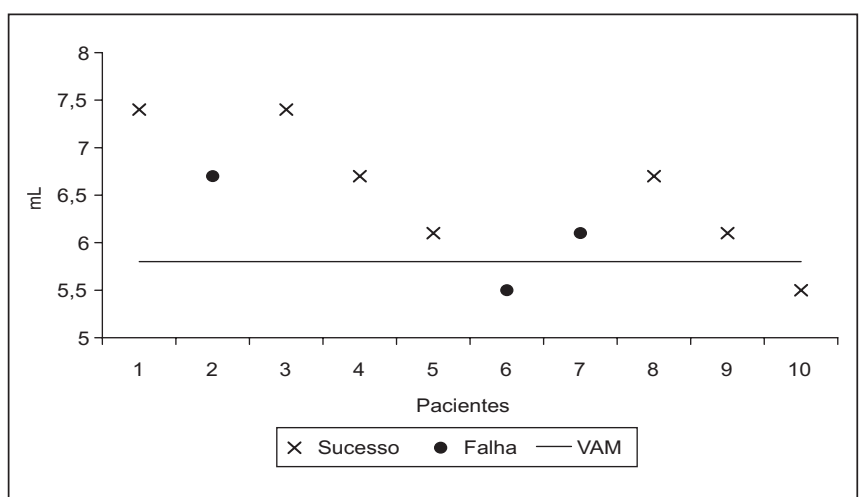

Figura 4 - Seqüência de Respostas dos Pacientes da Série 2 que Receberam Mistura Enantiomérica S75/R25 de Bupivacaína a $0,5 \%$

$x=$ sucesso (escore total de mobilidade ocular $\leq 2$ ), $\bullet$ = insucesso (escore total de mobilidade ocular $>2$ ). A linha horizontal representa o VAM $(5,8 \mathrm{~mL})$

Neste estudo foi utilizado o método de Massey e Dixon para pequenas amostras. Quando comparado à regressão logística e ao método de Massey e Dixon para grandes amostras, o método utilizado mostrou-se potente e capaz de determinar com igual precisão as ED50 de diversos analgésicos ${ }^{3}$. Sua principal limitação é a impossibilidade de determinar volumes efetivos em $95 \%$ dos casos ${ }^{2}$.

Apesar de o volume efetivo em $95 \%$ dos pacientes ser um valor de maior aplicabilidade clínica, dada a sua posição no platô superior da curva logarítmica de dose-resposta, este parâmetro não se presta para comparações entre diferentes fármacos, entre diferentes concentrações de um mesmo fármaco ou do efeito de drogas adjuvantes. Já o VAM, pela sua posição no ponto médio da porção ascendente da curva logarítmica de dose-resposta, é adequado para tais comparações 10,12

No bloqueio retrobulbar extraconal o anestésico local é depositado além do equador do globo ocular, junto ao cone, diferenciando-se do bloqueio peribulbar, em que a agulha tan- 
gencia o equador do globo ocular ${ }^{13}$. Neste estudo o bloqueio retrobulbar extraconal foi utilizado para evitar a necessidade de fracionar os volumes pré-determinados dos anestésicos locais entre dois locais de injeção.

Conclui-se que os volumes das soluções a $0,5 \%$ de bupivacaína racêmica, de levobupivacaína e da mistura enantiomérica S75/R25 de bupivacaína que produzem anestesia retrobulbar extraconal são semelhantes.

\section{Minimum Anesthetic Volumes for Extraconal Retrobulbar Block: Comparison between $0.5 \%$ Racemic Bupivacaine, Levobupivacaine and Enantiomeric Mixture S75/R25 Bupiva- caine}

Luiz Fernando Soares, TSA, M.D.; Ana Claudia de Melo Barros, M.D.; Gustavo Paiva Almeida, M.D.; Gustavo Luchi Boos, M.D.; Getúlio Rodrigues de Oliveira Filho, TSA, M.D.

\section{INTRODUCTION}

Minimum local anesthetic volume (MAV), corresponding to the effective volume for regional anesthesia in $50 \%$ of patients, was introduced as a research tool to compare $0.5 \%$ bupivacaine and $0.5 \%$ ropivacaine for femoral nerve block ${ }^{1}$. To determine MAV of a certain local anesthetic agent, its concentration has to be constant. The sequential allocation method, dependent on previous patient's response (Massey and Dixon's up-down method), was used to calculate MAV. Its primary advantages are decreased number of patients exposed to anesthetic failures and substantially smaller sample size ${ }^{2,3}$.

In addition to allowing comparisons among different local anesthetics ${ }^{1}$, MAV may be used to compare differents concentrations of the same agent or the effect of adjuvant drugs on local anesthetic volume for nervous blocks.

Specifically for retrobulbar extraconal block, local anesthetic volume injected in the orbit plays a critical role, since it is directly related to intraocular pressure increase ${ }^{4}$.

Racemic bupivacaine is effective for peribulbar block ${ }^{5}$. Its major disadvantage is cardiotoxicity primarily triggered by its dextrogyrous enantiomer ${ }^{6}$. The levogyrous enantiomer (levobupivacaine) is less cardiotoxic as compared to the racemic mixture ${ }^{7}$. Aiming at maintaining bupivacaine potency and decreasing its toxicity, an enantiomeric mixture was developed containing $75 \%$ levogyrous enantiomer and $25 \%$ dextrogyrous enantiomer (S75/R25), which is less toxic than the racemic mixture ${ }^{8}$.

Minimum effective volumes for bupivacaine, levobupivacaine or enantiomeric S75/R25 bupivacaine to induce ocular akinesia and surgical anesthesia in retrobulbar extraconal blocks have not yet been deter- mined. This study aimed at defining and comparing minimum anesthetic volumes of $0.5 \%$ racemic bupivacaine, levobupivacaine and enantiomeric S75/R25 bupivacaine for retrobulbar extraconal anesthesia.

\section{METHODS}

After the institutional Ethics Committee approval and their informed consent, participated in this study two series of patients of both genders, aged 18 to 85 years, submitted to elective cataract extraction by extracapsular or phacoemulsification technique. Patients were not premedicated and were monitored with cardioscopy, automatic noninvasive blood pressure and pulse oximetry. A peripheral vein was punctured with $20 \mathrm{G}$ catheter in the non-dominant hand for $0.9 \%$ saline infusion $\left(2 \mathrm{~mL} \cdot \mathrm{min}^{-1}\right)$.

Series 1 , aimed at comparing minimum anesthetic volumes of $0.5 \%$ racemic bupivacaine and $0.5 \%$ levobupivacaine, involved 20 patients receiving $0.5 \%$ bupivacaine $(n=9)$ or $0.5 \%$ levobupivacaine $(n=11)$. Series 2 , aimed at comparing minimum anesthetic volumes of racemic bupivacaine and $0.5 \%$ enantiomeric S75/R25 bupivacaine, involved 21 patients receiving $0.5 \%$ racemic bupivacaine $(n=11)$ or $0.5 \%$ enantiomeric S75/R25 bupivacaine $(n=10)$. Patients were allocated to each group by electronically randomized numbers. All solutions contained 1:200,000 epinephrine.

Retrobulbar extraconal injection was performed by transcutaneous inferior-lateral approach with $25 \mathrm{G} 2.5 \mathrm{~cm}$ needles. Needle was inserted $1 \mathrm{~cm}$ perpendicular to the skin and then was slightly advanced $1.5 \mathrm{~cm}$ upwards and inwards toward the orbital apex. After negative blood, CSF and vitreous humor aspiration, predetermined local anesthetic volume was injected. Immediately after, a $600 \mathrm{~g}$ oculopression was applied on the eye for 10 minutes. To calculate volumes to be used in each sequence, maximum volume was established as $10 \mathrm{~mL}$, which has been transformed into natural logarithm. From it, 0.1 units were subtracted until 10 posts below. These values were transformed in volumes $(\mathrm{mL})$ by calculating respective antilogarithms. Volume administrated to the first patient of each group was $7.4 \mathrm{~mL}$.

Subsequent volumes were determined according to the response of each previous patient in each group. Motility of every rectus muscles was evaluated 10 minutes after injection and the following scores were attributed to each muscle: 0 (absent), 1 (decreased) and 2 (normal). Total rectus muscles scores represented total eye motility score ${ }^{9}$. If total motility score was above $2,3 \mathrm{~mL}$ of $0.2 \%$ lidocaine were injected by superior-medial or inferior-lateral approach, result was considered a failure and next patient would receive the immediately higher volume. If not, result was considered a success and next patient would receive the immediately lower volume. Minimum anesthetic volumes were calculated using Massey and Dixon's formulae for nominal samples equal to $\mathrm{six}^{2,3}$. The natural logarithms of the volumes associated to blockade success were compared between groups by single factor analysis of variance ${ }^{2}$, considering significant $p<5 \%$. 


\section{RESULTS}

Bupivacaine and levobupivacaine standard MAV for series 1 were $6 \mathrm{~mL}$ and $5.7 \mathrm{~mL}$, respectively (Figures 1 and 2). Racemic bupivacaine and enantiomeric S75/R25 bupivacaine standard MAV for series 2 were $6.2 \mathrm{~mL}$ and 5.8 $\mathrm{mL}$, respectively (Figures 3 and 4 ). There were no differences among natural logarithms of volumes associated to blockade success $(F(2,24)=0.5 ; p=0.61)$. Supplemental injection was needed for 7 patients in each group, who are represented by circles on figures. After supplementation, all patients could be submitted to proposed surgical procedures.

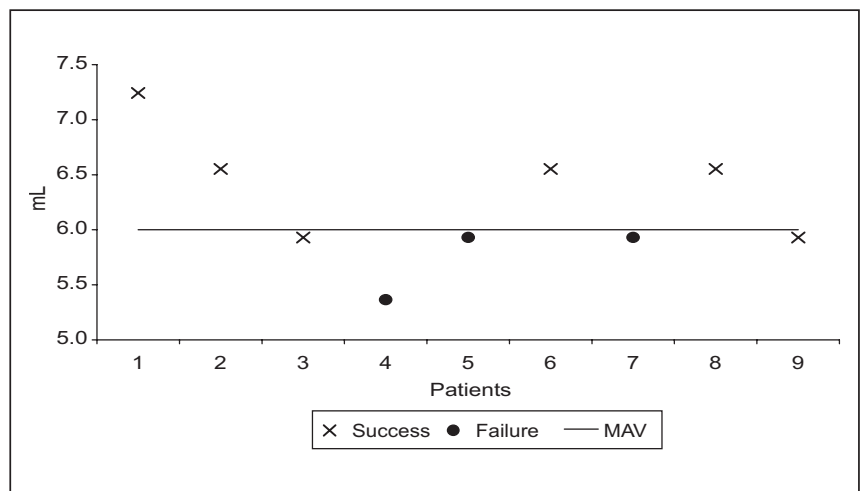

Figure 1 - Sequence of Responses of Series 1 Patients Receiving $0.5 \%$ Bupivacaine

$x=$ success (total eye motility score $\leq 2$ ), $\bullet=$ failure (total eye motility score $>2)$. Horizontal line represents MAV $(6 \mathrm{~mL})$

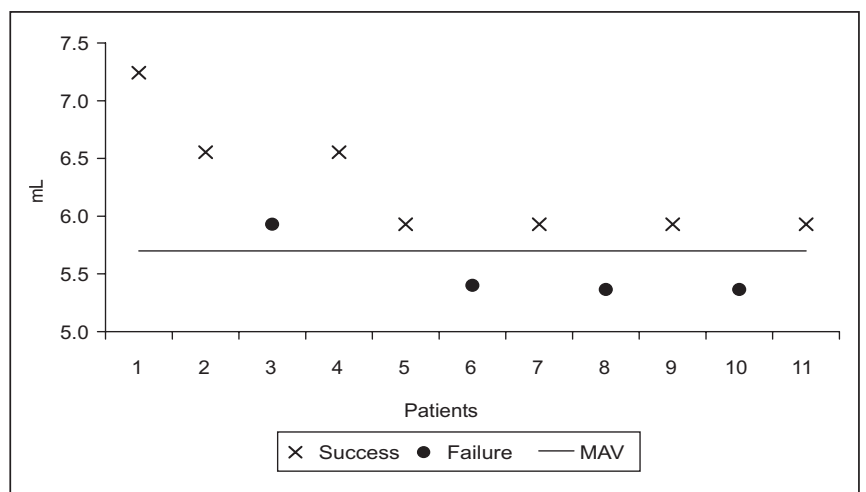

Figure 2 - Sequence of Responses of Series 1 Patients Receiving $0.5 \%$ Levobupivacaine

$x=$ success (total eye motility score $\leq 2$ ), $\bullet$ = failure (total eye motility score $>2)$. Horizontal line represents MAV $(5.7 \mathrm{~mL})$

\section{DISCUSSION}

Our results have not shown differences between minimum anesthetic volumes of racemic bupivacaine, levobupivacaine and enantiomeric S75/R25 bupivacaine.

Considering that the potency of a drug is the ratio between mass and effect ${ }^{10}$, that the same volume of two solutions with

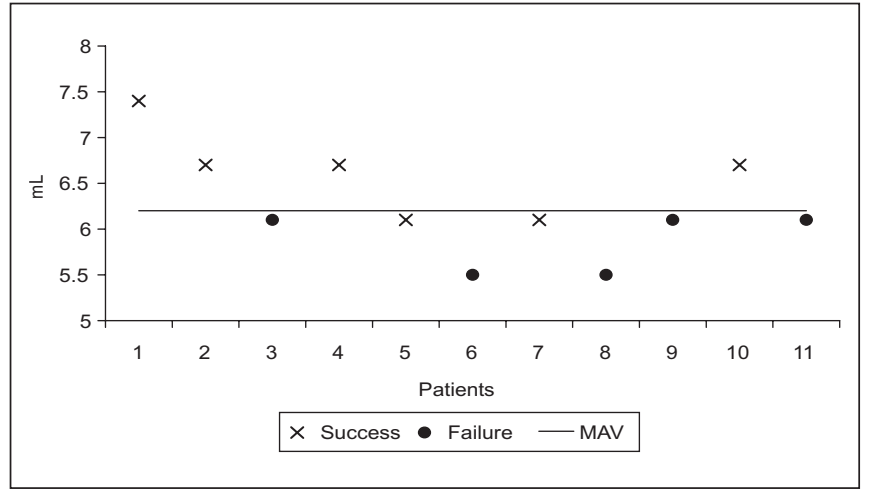

Figure 3 - Sequence of Responses of Series 2 Patients Receiving $0.5 \%$ Bupivacaine

$x=$ success (total eye motility score $\leq 2$ ), $\bullet=$ failure (total eye motility score $>2)$. Horizontal line represents MAV $(6.2 \mathrm{~mL})$

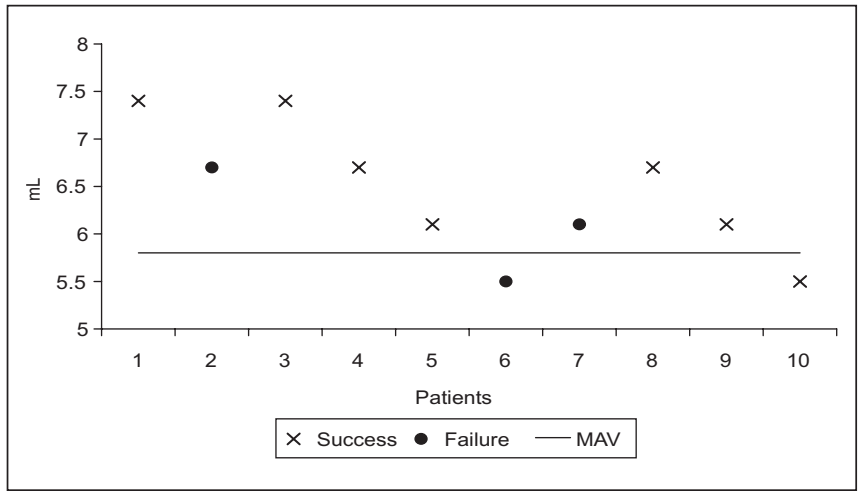

Figure 4 - Sequence of Responses of Series 2 Patients Receiving $0.5 \%$ enantiomeric S75/R25 Bupivacaine

$x=$ success (total eye motility score $\leq 2$ ), $\bullet$ = failure (total eye motility score $>2)$. Horizontal line represents MAV $(5.8 \mathrm{~mL})$

the same concentration of substances with the same molecular weight has the same mass, and that the molecular weight of both bupivacaine enantiomers is $288.4^{11}$, one may conclude that all solutions tested for retrobulbar extraconal block had similar potencies.

Our study has used Massey and Dixon's method for small sample sizes. As compared to logistic regression and Massey and Dixon's method for large sample sizes, this method was powerful and could determine with equal accuracy ED50 of different analgesic agents ${ }^{3}$. Its primary limitation is the impossibility of determining effective volumes for $95 \%$ of cases ${ }^{2}$.

Although being more applicable to the clinic due to its position in the upper plateau of the dose-response logarithmic curve, ED95\% is inadequate to compare between different drugs, different concentrations of the same drug or the effect of adjuvant drugs. MAV, however, for its position in the middle of the dose-response ascending logarithmic curve, is adequate for such comparisons ${ }^{10,12}$. 
Retrobulbar extraconal block deposits local anesthetics beyond the eye equator, close to the cone, being different from peribulbar block in which the needle is tangent to eye equator ${ }^{13}$. We have used retrobulbar extraconal block to prevent the need to fraction predetermined local anesthetic volumes between two injection sites.

Our conclusion was that similar volumes of $0.5 \%$ racemic bupivacaine, levobupivacaine and enantiomeric S75/S25 bupivacaine are needed for retrobulbar extraconal anesthesia

\section{REFERÊNCIAS - REFERENCES}

01. Casati A, Fanelli G, Magistris L et al - Minimum local anesthetic volume blocking the femoral nerve in $50 \%$ of cases: a double-blinded comparison between $0.5 \%$ ropivacaine and $0.5 \%$ bupivacaine. Anesth Analg, 2001;92:205-208.

02. Dixon WJ, Massey FJ - Introduction to Statistical Analysis. $4^{\text {th }}$ Ed, New York: McGraw Hill, 1983.

03. Lichtman $\mathrm{AH}$ - The up-and-down method substantially reduces the number of animals required to determine antinociceptive ED50 values. J Pharmacol Toxicol Methods, 1998;40:81-85.

04. Frow MW, Miranda-Caraballo JI, Akhtar TM et al - Single injection retrobulbar extraconal anaesthesia. Total upper eyelid drop as an end-point marker. Anaesthesia, 2000;55:750-756.

05. Birt DJ, Cummings GC - The efficacy and safety of $0.75 \%$ levobupivacaine vs $0.75 \%$ bupivacaine for retrobulbar extraconal anaesthesia. Eye, 2003;17:200-206.

06. Valenzuela C, Snyders DJ, Bennett PB - Stereoselective block of cardiac sodium channels by bupivacaine in guinea pig ventricular myocytes. Circulation, 1995;92:3014-3024.

07. Mazoit JX, Boico O, Samii K - Myocardial uptake of bupivacaine. Pharmacokinetics and pharmacodynamics of bupivacaine enantiomers in the isolated perfused rabbit heart. Anesth Analg, 1993;77:477-482.

08. Simonetti MPB, Ferreira FMC - Obtenção de novos anestésicos locais através da modificação da relação enantiomérica da bupivacaína racêmica. Rev Bras Anestesiol, 1999;49:(Supl): CBA156.

09. Nicoll JM, Treuren B, Acharya PA et al - Retrobulbar anesthesia: the role of hyaluronidase. Anesth Analg, 1986;65:1324-1328.

10. Ross EM - Pharmacodynamics. Mechanisms of Drug Action and the Relationship between Drug Concentration and Effect, em: Hardman JG, Limbird LE, Molinoff PB et al - Goodman \& Gilman's the Pharmacological Basis of Therapeutics, $9^{\text {th }} \mathrm{Ed}$, New York, McGraw-Hill, 1996;29-41.
11. Langerman L, Golomb E, Grant GJ et al - Duration of spinal anaesthesia is determined by the partition coefficient of local anaesthetic. Br J Anaesth, 1994;72:456-459.

12. Sonner JM - Issues in the design and interpretation of minimum alveolar anesthetic concentration (MAC) studies. Anesth Analg, 2002;95:609-614.

13. Edge KR, McClarty CP, Krige SJ et al - Comparison of an extraconal block with a retrobulbar-facial block combination for ocular surgery. A safe alternative technique to the combination of retrobulbar block and facial nerve block. S Afr J Surg, 1995;33:117-119

\section{RESUMEN}

Soares LF, Barros ACM, Almeida GP, Boos GL - Oliveira Filho GR - Volumen Anestésico Mínimo para Bloqueo Retrobulbar Extraconal: Comparación entre Soluciones a $0,5 \%$ de Bupivacaína Racémica, de Levobupivacaína y de la Mezcla Enantiomérica S75/R25 de Bupivacaína

JUSTIFICATIVA Y OBJETIVOS: El volumen anestésico mínimo (VAM) de un anestésico local es el volumen efectivo para anestesia regional en un $50 \%$ de los pacientes. El objetivo de éste fue calcular los volúmenes anestésicos mínimos de las soluciones a $0,5 \%$ de bupivacaína racémica, de levobupivacaína y de la mezcla enantiomérica $\$ 75 / R 25$ de bupivacaína para anestesia retrobulbar extraconal.

MÉTODO: Fueron estudiadas dos series de pacientes sometidos a extracción de catarata. En la serie 1, los pacientes recibieron bupivacaína a 0,5\% $(n=9)$ ó levobupivacaína a 0,5\% $(n=11)$. En la serie 2, los pacientes recibieron bupivacaína racémica a $0,5 \%(n=11)$ ó la mezcla enantiomérica $S 75 / R 25$ de bupivacaína a $0,5 \%(n=10)$. Los bloqueos fueron realizados por una inyección única ínfero-lateral. La movilidad de cada músculo recto fue evaluada después de 10 minutos como: 0 (ausente), 1 (diminuida) ó 2 (normal). La suma de los resultados constituyó el resultado total de movilidad (ETM) del globo ocular. El volumen inicial fue de 7,4 mL. Los volúmenes utilizados en pacientes subsiguientes correspondieron 0,1 unidad logarítmica mayor $(E T M>2)$ ó menor $(E T M \leq 2)$ que el logaritmo natural del volumen precedente. Fueron utilizadas las fórmulas de Massey y Dixon para cálculos de los VAM.

RESULTADOS: Los VAM de la bupivacaína racémica fueron 6 $m L$ y 6,2 mL, el de la levobupivacaína fue 5,7 $\mathrm{mL}$ y el de la mezcla enantiomérica de bupivacaína S75/R25 fue 5,8 mL. No hubo diferencia entre los grupos en lo referente a los volúmenes anestésicos efectivos.

CONCLUSIONES: Volúmenes semejantes de soluciones a 0,5\% de bupivacaína racémica, levobupivacaína o de la mezcla enantiomérica $S 75 / R 25$ de bupivacaína son necesarios para anestesia retrobulbar extraconal. 